DOI: 10.15642/JIIS.2015.9.1.79-100

\title{
THE TAQNIN OF INDONESIAN ISLAMIC LAW DYNAMIC
}

\author{
M. Noor Harisudin \\ IAIN Jember - Indonesia | mnharisudinstainjember@gmail.com
}

\begin{abstract}
Taqnin with the meaning of legislation on Islamic aspects actually has been a long story in Indonesia. It can be traced in Islamic courts in the archipelago. In the colonial era, the Dutch once accommodated certain aspects of Islamic law, until they decided to limit it. It especially can be seen in the institution of religious court. After the independence, the taqnin was reintroduced. It can be seen from the Piagam Jakarta (Jakarta Charter) which included the statement of "Belief in God Almighty by following the sharia for its adherents". However, this statement was edited to accommodate the aspiration of non-Muslims and the nationalists. In the following periods, legislation of certain aspects of Islam gained momentum in the late period of the New Order after Suharto sought political supports from Muslims. In the reformation era, the democratic atmosphere has opened a wider space for the efforts of taqnin.
\end{abstract}

Keywords: Taqnīn al-abkēm, fiqh, Islamic law.

\section{Introduction}

In the last decades, taqnin al-ahkām or the codification of certain aspects of Islamic law in Indonesia has been developed quite progressively. This is responded enthusiastically by the many Muslims. Fiqh, or Islamic jurisprudence, especially its private laws, initially was taught and practiced voluntarily among Muslims. Now, however, Islamic jurisprudence is categorized as one of the sources of law of Indonesian law system. Islamic law, or at least parts of it, may be 
enacted as law in Indonesia. Despite the fact that Indonesia is the biggest Muslim country in the world ${ }^{1}$, the global wave of religious resurrection also swept Indonesia since decades ago. Therefore, many elite are now apparently more religious. In addition, in the era of democracy, Muslims' view, who are majority, now counts. Winning their hearts and minds by supporting certain aspects of Islamic law, albeit artificial, is now a norm in daily politics in Indonesia. ${ }^{2}$

This article, however, is not intended to discuss the political dynamic between Muslims and seculars or between scripturalist Muslims and substantive Muslims on the issue of codification of Islamic law in Indonesia. Instead, it will discuss aspects of Islamic law should be enacted, how the best way to enact that law without upsetting the oppositions, and which Islamic law suits the context and the culture of Indonesia. This is because there are so may interpretation on Islamic law an Indonesia is not a vacuum since Islamic law is one source of law, in addition to adat (customary) law and the law coming from the Dutch 3 .

Admittedly, the legal tradition of the Dutch has been rooted in Indonesia for centuries, all law schools in Indonesian universities follows this tradition. Adat law and Islamic law is only considered insignificant part of the study. Blatantly, it also deny the study of Islamic law in Islamic higher education institutions. According to a Muslim legal expert, that applying law as an unchangeable codification of law without considering the context of where and when it is created is unwise act. As it is stated by Ibnu Qayyim al-Jauziyah, understanding

\footnotetext{
${ }^{1}$ It is based on Habiburrahman statement that Indonesia is Islamic country. It can be seen in its five basic principles called Pancasila which were in accordance to the Islamic teaching. Even though it is not explicitly stated that Indonesia is TheoDemocratic state but Pancasila was placed the principle of faith to the God as its first principle. See, Habiburrahman in Rekonstruksi Hukum Kewarisan Islam di Indonesia, (Jakarta: Prenada Media, 2011), p. 25.

2 One example for this is the enactment of Islamic Banking Law in 2008 by the President Susilo Bambang Yudhoyono, which KH. Abdurrahman Wahid suggests it was no more than an image building to get Muslims supports in the upcoming presidential election. See Abdurrahman Wahid, 'Syari'atisasi dan Bank Syariah,' in Islamku, Islam Anda, Islam Kita: Agama Masyarakat Negara Demokrasi, Jakarta: the Wahid Institute, 2006).

${ }^{3}$ As it has known that there are three subjects applied in our national law. The first is the Islamic law, the second is the custom law and the third is the law inherited from the Dutch.
} 
law should dig deeper into its philosophy, otherwise we will be trapped into meaningless letters of law ${ }^{4}$. Fiqh stated by various schools of Islamic thinking should be corrected and modified to make it applicable for Indonesian context. It then is induced into Indonesian law system. In with that philosophy, since 2004, Indonesia launched Prolegnas (Proyek Legislasi Nasional or National Project of Legislation) which aimed at replacing archaic Dutch legal heritage with national based laws. ${ }^{5}$ In this context, Islamic law may play significant role.

As it is commonly known that based on its applicability, Islamic law (figh) can be classified into two: the first is formal juridical law which means it has been codified into national law system. The second is the normative fiqh which is not covered in the national law ${ }^{6}$. The first is called as the positive law. The second is just a theory of Islamic jurisprudence. Another classification also is proposed by M. Atho Mudhar who says that there are four products of Islamic law in Indonesia: fiqh theoretical books, religious court rulings, Islamic positiv laws (acts), and Islamic scholars' fatwas. ${ }^{7}$

In general, there is still a handful of qānu law) in Indonesia. ${ }^{8}$ However, it can be an improvement compared to the previous period. Furthermore, it is known that the history of

${ }^{4}$ Ibnu al-Qayim al-Jauziyah in I'lam al-Muwaqi'in stated that:

$$
\text { و الجمود علي المنقولات ابدا ضلال في الدين و جهل بمقاصد علماء المسلمين و السلف الماضيين }
$$

Means: "blindly keeping the perspective based on merely quotations is a religious mistake and misunderstanding on the aims and goals of the salaf scholars in the past." Ibnu al-Qayyim al-Jauziyah, A'lam al-Muwaqi'in, Section III, p. 99.

5 The Prolegnas actually started in 1977, but gained greater legal framework in 2004 with the Law No. 10. See BPHN, Tiga Dekade Prolegnas dan Peran BPHN (Jakarta: BPHN, 2008)

${ }^{6}$ See, Dadan Muttaqien, Legislasi Hukum Islam di Indonesia dalam Perspektif Politik Hukum, (Paper presented in Postgraduate program, Indonesian Islamic University (UII) Yogyakarta, 6 March 2009).

7 M. Atho Mudzhar, "Pengaruh Faktor Sosial Budaya terhadap Produk Pemikiran Hukum Islam," Jurnal Mimbar Hukum 4, II Jakarta: Al-Hikmah dan Ditbinbaperta Islam, 1991), pp. 21-30.

8 In sociological jurisprudence, the term positif law is differentiated from living law. Its prominent figure is Roscoe Pound (1870-1964). In his book, An Introduction to The Philosophy of Law, he insisted that law function at least to guarantee the safety of the society. 
qānun in Indonesia is never been easy because of dynamic of sociopolitical development as it discussed below.

\section{Fiqh and Taqnin; Definition, Correlation and History}

Etymologically, fiqh means understanding. Meanwhile, it means a science on shari'a law in its application based on detailed theorem. As a shari'a, it does not accommodate customary and positive law. Since it focuses on the implementation, it neglects i'tiqadiyah and qalbiyah law. I'tiqadiyah concerns with worship and faith to the Al-mighty, meanwhile qalbiyah concerns with the law based on Sufism. ${ }^{9}$

Al-Khudari Bek in Tarikh al-Tasyri' al-Islamy divides the period of Islamic law development into six phases of tashri (legislation): the first is the period of Muhammad. In this period between $610 \mathrm{AD}$ until 632 $\mathrm{AD}$, the emerging problems were directly addressed by the prophet Muhammad. The second is the period of kibar as-sababah or senior companions of the Prophet period which was the period khulafaur rashidin (four rightly guided caliphs) for around 30 years, $632 \mathrm{AD}$ until $661 \mathrm{AD}$. The third is the period of junior companions. It was begun from the beginning of Umayyad dynasty in 661 AD until the turn of the first century Hijra in 721 AD. The fourth is the period when figh has become an independent and autonomous science or field study started from the initial period of the second hijrah to the third century (722 AD - $822 \mathrm{AD})$. The fifth is a long period of refinement and consolidation of fiqh starting from the beginning of the fourth century of hijrah until the fall of Baghdad in the hands of the Mongols in 1258 AD. The sixth, the taqlid period started from the downfall of Baghdad up to now ${ }^{10}$.

Rif al Ka'bah added that Muslims recently has entered the seventh period of figh development. This period is marked by the strengthening the role of the state vis-à-vis religion (Islam). While in the past Islamic law is independent from the state interference with the ulama as the main actors of the law, the modern state is hegemonic. Law is now part of state's authority. Islamic law must undergo codification, compilation and ijtihad periods on contemporary problems to be done by formal institution of the state. This

\footnotetext{
${ }_{9}^{9}$ See, M.N. Harisudin, Ilmu Ushul al-Figh I (Jember: IAIN Press, 2014), p. 1.

${ }^{10}$ Muhammad al-Khudari Bek, Tarikh Tashrì' al-IsTami (Beirut: Dār al-Fikr, 1988), pp. 5-

6. See also, Noel J. Coulson, The History of Islamic Law (Edinburgh: n.p., 1964), pp. 5-15.
} 
codification aims at enriching and strengthening the state law ${ }^{11}$. This period is a period commonly called as taqnin period. It is an effort to include the Islamic law into national law system.

Etymologically, the word taqnin is derived from the word qannana which means formulating law. Meanwhile the word qanun means measure of something and it can also mean "way" (tariqab). ${ }^{12}$ A Muslim legal philosopher Sobhi Mahmasani stated that the qannun is derived from the Greek word Canon. ${ }^{13}$ Other expert considered it as a Persian word. In the dictionary of al-Munawir, it means compilation of established rules, laws and norms. ${ }^{14}$

The term taqnin al-ableam means collecting Islamic jurisprudence and its principles concerning with the problem of social relationship, arranging them systemically and stating them in a brief, clear and unbiased language in chapters, articles and paragraphs chronologically in numbers assigned by the government as the law that should be implemented by the law agencies in the society ${ }^{15}$. Therefore, the word taqnin refers to the codification of certain aspects of Islamic law sanctioned by the state so that it is legally binding and implemented for all subjects of the state.

To justify the role of the state as an agent to implement Islamic law, there is an Islamic legal maxim stated that bukmu al-hăkim yulizimu wa yarfan al-kbilaf which means that the law of the authority is binding without exception. Taqnin refers to the process while qānun refers to its product. Some Muslim leaders consider the efforts done by the government to codify aspects of Islamic law is significant as a guideline for the judges in making the judicial decisions ${ }^{16}$.

${ }^{11}$ Rifal Ka'bah, Hukum Islam di Indonesia (Jakarta: Universitas Yarsi, 1999), p. 52.

12 Ibrahim Anis, al-Mu'jam al-Wäsith, Section 2, p. 763.

${ }^{13}$ Sobhi Mahmasani, Filsafat Hukum Islam (Bandung: al-Maarif, 1976), p. 27

14 Ahmad Warson Munawir, Kamus Munawwir (Yogyakarta: Yayasan Ali Maksum Ponpes Krapyak Yogayakarta, 1984), p. 1252.

${ }^{15}$ Mushtafa al-Zarqa, al-Madkhal al-Fiqh al-'Am, Section I (Beirut: Dār al-Qalam, 1418 H), p. 313. Compare to Abdurrahman Ibn Sa'ad Ibn 'Ali al-Syatsri, Hukm Taqnin alShari'ah al-Istamiyah, (Riyadh: Dār al-Hāmi’ lil al-Nashri wa al-Tausi'i, 1428), p. 15.

16 Compare to the definition of fatwa: "Al-ikhbar bilhukmi syar'i la 'ala wajhil ilzam". It means a non-binding legal opinion. It is done by the ulama. In Indonesia fatwa is done by several Muslim organizations for their members, such as Muhammadiyah, Nahdlatul Ulama, Persatuan Islam, and Majelis Ulama Indonesia. 
historically speaking, codification of Islamic law was proposed as early as the second century Hijra. Ibnu Muqaffa (w. 756 H/140 H) secretary of the state of the second caliph of Abbasid dynasty is the first person who proposed taqnin to the caliph of al Manshur. According to him, various Islamic doctrines was to be codified and passed as the law to make a similar, unified and binding law for the qadhi. Ibnu Muqaffa stated that the one who had a right to make or decide qanun is the caliph who made him able to rule the military and public and covered all kinds of problems based on Al-Qur'an and Hadith ${ }^{17}$.

The efforts to propose taqnin can be seen from the statement of Ibnu Muqaffa to the caliph of al-Manshur:

The most important that should be considered by commanders of the faithful (the caliph) is conflicting rules governed in various region of Abbasid dynasty on the same subject. This difference of rules and laws endanger the lives, the properties and the dignity of people. Therefore, the caliph should collect the strongest and relevant Islamic law that was applied divergently as the rule and the law applied in all courts. It functions as the guideline binding for all judges. Therefore, the caliph should appoint special officer to collect the appropriate law and applied it in his court. ${ }^{18}$

Ibnu Muqaffa taqnin proposal was not warmly accepted by al Manshur. However, in the following periods, the caliph asked permission Imam Malik, the renowned Muslim jurist at the time, that the latter's treatise on Islamic jurisprudence called al-Muwattha' to be made as the code for the whole empire. Imam Malik refused because the treatise might contain mistakes and he did not want to be blame hereafter.

In the period of Ottoman Empire, Sultan Sulaiman made qānun or qanun name as an official law in the age of Uthmani in 1520-1560 AD. The qanun name assigned by him regulated the amount of the salary for the army and non muslim police officer, the criminal law, the land law and the law of war. In 1877, a canon named Majalah al-Abkam alAdliyah which regulated the law of contract based of Hanafi school of law.

${ }^{17}$ Josep Schacth, Pengantar Hukum Islam (Bandung: Nuansa, 2010), p. 95.

${ }^{18}$ Ibid., p. 616. 
Moghul dynasty in India also passed a qānūn called as fatāwa Alamghiriyah. This name was derived from the ascription name of Sultan Aurangzeb (1658-1707). In 1772, British colonized India and to administer legal aspect in its colonial territory, they created a fusion of Islamic law and British common law which was known as Muhammadan Law. ${ }^{19}$ This fusion seemed conceivable considering similarity of British common law and Islamic jurist law. Therefore, taqnin in India was combined with other law.

Meanwhile, in Saudi Arabia, in the reign of King Abdul Azis, the leader of sharia high court named Ahmad bin Abdillah al-Qari also compiled Islamic law based on Ahmad Ibn Hanbal school which then was summarized by Al-Qari. This compilation consists of the discussion of 2.382 problems which was entitled al-Abkam al-Adliyyah. This compilation, unfortunately, was opposed by the Islamic theologians. ${ }^{20}$

Like other Islamic country, the taqnin of Islamic law in Indonesia also has a long history. Starting from pre colonization period up to now, it was influenced and resulted from various factors. The most influential factors are the administrative and political context of the created taqnin.

\section{The Taqnin of Islamic Law Dynamic in Indonesia}

\section{Pre-colonial period}

When Islam came to archipelago, it did not come with force. Instead, it came peacefully. One of the results of this reasonable peaceful process, there is assimilation between Islamic values and local customs, including in the area of law. Local law, which later called as adat is applied alongside with Islamic law in different gradation. Sometimes, Islamic law is absorbed entirely into adat, in other place Islamic law replaced adat, and occasionally adat remains strong in the presence of Islamic law. According to Reid, as reported by Sunanto, Acheh in the northern tip of Sumatra and Banten in the Northwest of Java are the two regions in which Islamic law was applied reasonably

\footnotetext{
${ }^{19}$ Josep Schatch, Pengantar Ilmu, pp. 145-148.

${ }^{20}$ Kitab at-Taqnin baya at-TahTil wa at-Tahrim, p. 1. Read also a more completely, on Islamic law in various countries in Tahir Mahmood, Personal Law in Islamic Countries (New Delhi: Times Press, 1987).
} 
comprehensive, including Islamic penal law. ${ }^{21}$ Especially on the orthodoxy of Banten, Martin van Bruinessen also acknowledged it and reported that there was early Islamic education for Kadi in Banten named pesantren Karang. ${ }^{22}$ Thus, Islamic law has replaced HinduBuddha in various ways. For instance, Pengadilan Sitinggil was replaced by Pengadilan Serambi and a specified expert on Islamic law were appointed as the judge bearing the name of Kadi (qadhi). In other side, in the period of Islamic kingdom, the judicative power which previously held by tahkim institution of the kingdom was given to the court. It aims to strengthen the implementation of Islamic law. Therefore Pengadilan Serambi emerged in Java, Mahkamah Syariah in Sumatra and Kerapatan Qadhi in Banjar and Pontianak. ${ }^{23}$ The main aspect applied in the court is Islamic marriage law. The process of islamization in Indonesia, however, did not finish when the Western power came to Indonesia. Islam that teaches Perang Sabil (the holy war against the infidels) became the power of resistance against the western power, be it Portuguese and later the Dutch. ${ }^{24}$

\section{The Colonization Era}

According to Bustanul Arifin, the colonial policy on Islamic law and religious institution of court reflects the whole consequences of the politic of colonial law to the Indonesian Islamic law. Because Islam is symbolized as an opposition against the Dutch in many parts of archipelago, it is undeniable that colonial law neglected the implementation of Islamic values and it obstructed the Islamic law from being the positive law in Indonesia ${ }^{25}$. Many religious institutions such as family court which had existed since the Islamic kingdom

\footnotetext{
${ }^{21}$ Musyrifah Sunanto, Sejarah Peradaban Islam Indonesia (Jakarta: Rajawali Press, 2007), pp. 133-4

22 Martin van Bruinessen, Kitab Kuning, Pesantren dan Tarekat: Tradisi-tradisi Islam di Indonesia (Bandung: Mizan, 1999), pp. 24-5

23 Bustanul Arifin, Pelembagaan Hukum Islam di Indonesia (Jakarta: Gema Insani Press, 1996), p. 78.

${ }^{24}$ Merle C. Ricklefs, Sejarah Modern Indonesia, translated by Dharmono Hardjowidjono (Yogyakarta: Gadjah Mada University Press, 1991).

25 See, Bustanul Arifin, Eksistesi, Konsolidasi dan Aktualisasi Pengadilan Agama (Paper presented in IAIN Syarif Hidayatullah, Jakarta, 22 Desember 1993), p. 28. Also read, Aqib Suminto, Politik Islam di Hinda Belanda (Unpublished dissertation, IAIN Syarif Hidayatullah Jakarta, 1985).
} 
period was incorporated into Dutch legal system and later was gradually stripped of its authority and competence and finally became insignificant part of that system.

At least, when Netherland East Indies took over the authority from the VOC, it located potential challenges that could be done through the religious institution of the court. This standpoint is quite different from their initial period which tended to accommodate the Islamic law in Indonesia. Therefore in the colonial era, the development of the taqnin can be divided into two phases: the accommodative and the resistant periods.

The first is the accommodative period. It has been known that from the beginning, Islamic law has involved in the acculturation process with various tradition such as Aceh, South Sulawesi, Minangkabau, Riau and Banten. In those regions, Islamic law had been accepted more prevalently than in other regions. In Minangkabau of West Sumatra for instance, there is a proverb saying that "adat basandi syara/ custom is based on sharia", "syara basandi kitabullah/"sharia is based on the holy books from God" and "syara mengata, adat memakai/what the sharia says, the custom will follow" 26 .

At first, the Dutch did not intervene the Islamic law existed in Indonesia. However, as the Dutch gradually gained power, they slowly passed the policy to restrict the Islamic law. In May, 1760, the VOC (1602-1799), passed Resolutie der Indege Regeering which regulated the laws on marriage and inheritance based on Islamic law to be applied in VOC courts on Indonesian cases. This resolution was commonly known as Compendium Freiyer which was the first Islamic law legislation in Indonesia. ${ }^{27}$

The accommodation done by the colonial Dutch can also be seen in the existence of Compendium der Voornamiste Javaanche Wetten Naukeurig Getrokken Uit Het Mohammeaanche Wetboek Mogharrer. The content of this compendium was taken from the Imam Rafi'i book of al-Muharrar. Substantially, it regulated Islamic criminal law and it was implanted in Semarang, Central Java. B.J.D. Clotwitjk also passed the law which gave a space for the implementation of Islamic

\footnotetext{
26 Taufiq Abdullah, Sejarah dan Masyarakat (Jakarta: Pustaka Firdaus, 1987), pp. 104127.

${ }^{27}$ Idris Ramulyo, Azas-Azas Hukum Islam (Jakarta: Sinar Grafika, 1997), p. 12.
} 
law in South Sulawesi..$^{28}$ Later in 1882, the Dutch issued the staatsblad no. 152 which implicitly stated that the Dutch acknowledge the Islamic court dealing with marriage issues in Java and Madura. ${ }^{29}$ This was the last accommodative policy of the Dutch toward Islamic law in the archipelago.

The second is the resistance period. The religious court (priestraad) which regulate marriages of Muslims were gradually stripped from its authority. While it previously enjoyed some degree of independence, in the next phases, the Dutch perceived the court as a hindrance for their colonial interest. Therefore, they then implemented a quasi-court which put the marriage court under the authority of public court. ${ }^{30}$ This was applied in Java, Madura and South Kalimantan. ${ }^{31}$

In this period, The Dutch applied the concept of Het Indiche Adatrect pioneered by their religious adviser Van Vollenhoven (1874$1933)$ and S.S. Hurgronye (1857-1936) who believe that Islamic law is not applicable in the archipelago as long as not recognized by adat law in the region. It theory notoriously name as the theory of Receptie. It means that the existence of Islamic law depended on the customary law. W2 With this theory, the Dutch had a rationale to create a commission to reevaluate the authority of the court on marriage in Java and Madura. Through STB No. 116, this commission recommended to repeal the authority of the court on inheritance cases, since on that aspect of law, adat was applied.

The Dutch resistant standpoint to taqnin was the result of their colonial policy. It was done in a subtle way through the theory of

\footnotetext{
28 Ahmad Rofiq, Pembaruan Hukum Islam di Indonesia (Yogyakarta: Gama Widya, 2001), p. 59.

${ }^{29}$ From this, the theory Receptio in Complexu was created by Lodewick William Christian van den Berg (1845-1927). It means that Indonesian Muslims has accepted Islamic law completely. Based on this theory, the existence of Islamic law is equal to other law system. See, Muhammad Daud Ali, Hukum Islam Jakarta: Raja Grafindo Persada, 1993), p. 219.

${ }^{30}$ Yaswirman, Hukum Keluarga (Jakarta: PT Rajda Grafindo Persada, 2013), p. 52

31 After the independence of Indonesia, the authority of the court on religious matters in Sumatra has ever been doubted its legality. Therefore the 1957 government act no 45 to eradicate this doubt. However, it is strange that this act did make the same courts outside Java, Madura and south Kalimantan a real and functional court. It means that this act did not have an impact. See, ibid, 53.
}

32 S. Lev, Hukum dan Politik di Indonesia (Jakarta: LP3ES, 1990), pp. 424-438. 
Receptie. However, substantially it was a marginalization efforts of the taqnin of Islamic law in the Dutch national law system. Admittedly, this theory influences post-independence lawyers and legal experts who studied in universities which were originally set up by the Dutch in Indonesia.

As the result, the taqnin of Islamic law during Dutch colonial period is virtually existed. Religious court which was an icon of the implementation of Islamic law in the archipelago had been curtailed in at least two ways; is authority is subdued under public court and its competence was stripped and replaced by adat law and/or Dutch law.

\section{Taqnin in the Period of Indonesian Post Independence (1945 - Now)}

In this period, the space for the implementation of Islamic law as the positive law has been actually existed. Dadan Muttaqien quoted Abdul Ghani Abdullah stated that there were three rationales for the implementation of Islamic law in Indonesia. The first is the philosophical reasoning that Islamic teaching has been the way of life, moral and laws aspiration of most of Indonesian Muslims that has shown its significant role. The second is sociological reasoning. It has underlined that the living law of Indonesian community is based the Islamic law through the concept of customary law. The third is juridical reasoning as it has been stated in the article of 24, 25 and 29 of the 1945 Indonesian constitution that make it legal to implement the Islamic law. ${ }^{33}$

Therefore, it is not surprising that the aspiration to legislating (taqnin) Islamic law emerged in Indonesia since the first day of independence among Muslims. First, formally, it is reflected in the principles of Pancasila (the state five principles) as it was originally stated in the first principle of Jakarta charter, the document in which Pancasila was originated from: "belief in one God by observing sharia for the muslims." However, this initial statement of principle stated in Jakarta Charter was replaced by omitting its last part ("observing sharia for the Muslims") to accommodate the aspiration of the seculars and people from the east part of Indonesia who are mostly non-Muslims. ${ }^{34}$

\footnotetext{
${ }^{33}$ See, Muttaqien, Legislasi Hukum Islam.

${ }^{34}$ Hartono Mardjono, Menegakean Shariat Islam dalam Konteks Keindonesiaan (Bandung: Mizan, 1977), p. 125. Compare to Endang Saifudin Anshari, Piagam Jakarta 22 Juni 1945 (Bandung: Pustaka Perpustakaan Salman ITB, 1981), p. 14. Muhyar Fanani,
} 
As a result, the principle of belief in one god then interpreted that every Indonesian citizen must observe a religion of his or her choosing. In this period, the situation was not conducive for any legislation for three reasons. The first was the police action by the returning Dutch, which forced the newly declared independent country channeled all energy to gain full independence through diplomacy as well as armed resistance. Once the independence was fully gained in 1949, there was endless debate concerning the nature of independent Indonesia between an Islamic state and secular state until 1959. The dissatisfaction of certain Muslims to the prolonged and fruitless political process led them to declare their own version of Islamic state in Indonesia and challenged the central government militarily in DI/TII movement. ${ }^{35}$ Virtually, the only law concerning Islamic law in this period was merely a national version of the Dutch law on marriage registration for Muslims (Law No. 2/1946).

Secondly, the legislation of Islamic law implemented in the period of Suharto's New Order era (1966-1998), was marked by the enactment of Law No. 1/1974 on Marriage. It is quite an achievement considering Suharto's New Order was an authoritarian regime backed by the military. Although initially the bill was secular and civil marriage, ${ }^{36}$ at the end Muslim representative in the parliament were able to make this law based on Islamic law with some exceptions. ${ }^{37}$ For example, in the article of 12 paragraph 1 it is stated that the legality of a marriage is based on the law of religion. This is sharp contrast with its bill which proposed a civil marriage. ${ }^{38}$ Admittedly, the role of Suharto

Membumikan Hukum Langit: Nasionalisasi Hukum Islam dan Islamisasi Hukum Nasional Pasca Reformasi (Yogyakarta: Tiara Wacana, 2008), p. 86.

35 BJ. Boland, Pergumulan Islam di Indonesia 1945-1970, translated by Sjafroedin Bahar (Jakarta: Grafiti Press, 1985).

${ }^{36}$ Kamal Hasan, Modernisasi Indonesia: Respon Cendekiawan Muslim (Jakarta: Lingkaran Studi Indonesia, 1987), p. 190.

37 At that time, there were 3 fractions from parties in the parliament: the fraction represented the Party of Functional Group (Partai Golongan Karya/Golkar), Indonesian Democratic Party (Partai Demokrasi Indonesia/PDI), and United Development Party (Partai Persatuan Pembangunan/PPP). After there was a fusion among parties in 1971, three parties were left:, Golkar, PDI and PPP added by a fraction represented the Army (ABRI).

38 Rachmadi Usman, Perkembangan Hukum Perdata dalam Dimensi Sejarah dan Politik Hukum di Indonesia (Jakarta: Grafiti, 2003), p. 196. 
and his military representatives in the parliament is decisive in the enactment of this Islam-based marriage law. The regime believed that marriage is a very important aspect of a Muslims life. Thus, having a law on marriage which is Islamic is a must. Otherwise, there would be unrest among Muslims as a result.

This law was finally agreed in a parliament session as the fixed law on 22 December 1973. Institutionally, it was passed by the Legislative Assembly as The Law no 1 of 1974 on Marriage on 2 January 1974. Then it was effectively applicable since 1 October 1975.39

In brief, it can be stated that the taqnin of Islamic law is result of political contestation. It is in line with the statement of Said Agil Munawar that the positive law is a product of political power. ${ }^{40}$ The existence of the taqnin is determined by this political struggle. ${ }^{41}$

The Suharto's authoritarian regime of New Order put aside all elements that are hindrance or opposition to its goals of political stability an economic development. Islamic aspiration, which in the past was a source of political instability, is not an exception. Therefore, the taqnin of Islamic law had been marginalized by this regime's $\mathrm{s}$ regulation and policy. The regime also insisted that its interpretation of Pancasila was the only interpretation and had to be obeyed by all citizens. In addition, all social organizations must register to the authority and must acknowledge Pancasila as their organizational principle. ${ }^{42}$ Consequently, virtually all Islamic social organization obeyed this policy, albeit reluctantly.

\footnotetext{
39 Ibid., p. 198. Compare to Abdullah Azis Thaba, Islam dan Negara Politik Orde Baru (Jakarta: Gema Insani Press, 1996), pp. 239-240.

${ }^{40}$ Said Agil M unawar, Hukum Islam dan Pluralitas Sosial (Jakarta: Pena Madani, 2004).

${ }^{41}$ Law is political product. Therefore discussing the politic of the law is describing the political influence toward the la w. Bellfroid explained that the politic of the law is the process of the formation of ius contituendum (the assigned law) to meet the change in the society. It is also correlated to the public policy as Thomas Dye berarti stated "whatever the government choose to do or not to do". It can also be defined as the development of the law. Sri Wahyuni, "Politik Hukum Islam di Indonesia; Studi Terhadap Legislasi Kompilasi Hukum Islam," Jurnal Mimbar Hukum, 59, XIV (2003), p. 74. Sirajuddin, Legislasi Hukum Islam di Indonesia (Yogyakarta: Pustaka Pelajar, 2008), p. 134.

42 Faisal Ismail, "Pancasila as Sole Basis for all Political Parties and for all Mass Organizations: An Account of Muslims' Responses," Studia Islamika, 4, 3 (1996), pp. $1-92$
} 
The tight grip of the regime on social and political lives of its citizens had made it impossible for citizens to propose a legislation which was contradictory to the regime's desire. Instead, this would be considered a subversive (an act of treason or dissidence) with a grave consequence. This made the taqnin of Islamic law became a closed subject.

However, there were Islamic movements that successfully operated under the radar of the New Order Regimes since the decades of 1980s. They were inspired by the global movement of religious fundamentalism. They advocated the islamization of all aspects of life, including public and political ones. ${ }^{43}$ These newly converted Muslims were university students which later after graduation became prominent personalities within government agencies. They found a patronage in BJ. Habibie, a devout Muslim who was the Minister of Science of Suharto himself. The situation then was about to change in favor of Islamic causes.

The change has initially begun in 1990s in line with the political change in Indonesia when Suharto reportedly upset with the military and turned into a new allies, urban Muslim intellectuals. The opportunity to do the taqnin of Islamic law was reopened. It occurred when the government established an Islamic organization namely Association of Indonesian Muslim Intellectual (Ikatan Cendekiawan Muslim Indonesia/ICMI) in 1990s which became the government instrument to speak its policy. Although pros and cons among Muslims surround the position of ICMI as an agency to the state, this organization, however, has brought some positive impacts. One of them is the establishment of government regulation which was the taqnin of Islamic law in Indonesia. For example, the enactment of Kompilasi Hukum Islam (compilation of Islamic law) through the president instruction in 1991 which was resulted from the good atmosphere in the organization of ICMI and the government. ${ }^{44}$ A year later, a Law No 7/1992 allowing the opening of shari'a compliance banking and finance was also enacted.

\footnotetext{
43 Abdul Aziz, et. al, Gerakan Islam Kontemporer di Indonesia (Jakarta: Diva Pustaka, 2006).

44 M. Syafi'i Anwar, Pemikiran dan Aksi Islam Indonesia: Sebuah Kajian Politik tentang Cendekiawan Muslim Orde Baru (Jakarta: Paramadina, 1995), p. 9. Read also in detail: M. Syafi'i Anwar, Politik Akomodasi Negara dan Cendekiawan Muslim Orde Baru: Sebuah Retrospeksi dan Refleksi (Bandung: Mizan, 1995).
} 
After Reformation era of 1998, the opportunity became wider. The democratic climate brought by the new government has opened a wider space for proposing Islamic law. As the result, the establishment of the Law No 38/1999 on the management of zakat was the first taqnin of Islamic law in this era. Other regulations based on taqnin were also passed which will be discussed further in the following session.

In this Reformation era, the climate to propose the taqnin was much better. Almost all inputs of regulation based on Islamic law could be accepted by the government. Unfortunately, since Indonesia is not formally an Islamic state and there are non-Muslim citizens as well, some argued that the establishment of many Islamic regulation would change Indonesia into a theocratic state. This argument also proposed by certain element of Muslim community in Indonesia who also opposed greater legislation of Islamic law.

As the result, there are some difficult eras for the acceptance of the taqnin in Indonesia. There are also some other periods when it was easier to make the positive laws in Indonesia. This process is illustrated in the following scheme.

Figure 1. The Process of Taqnin in Indonesia ${ }^{45}$

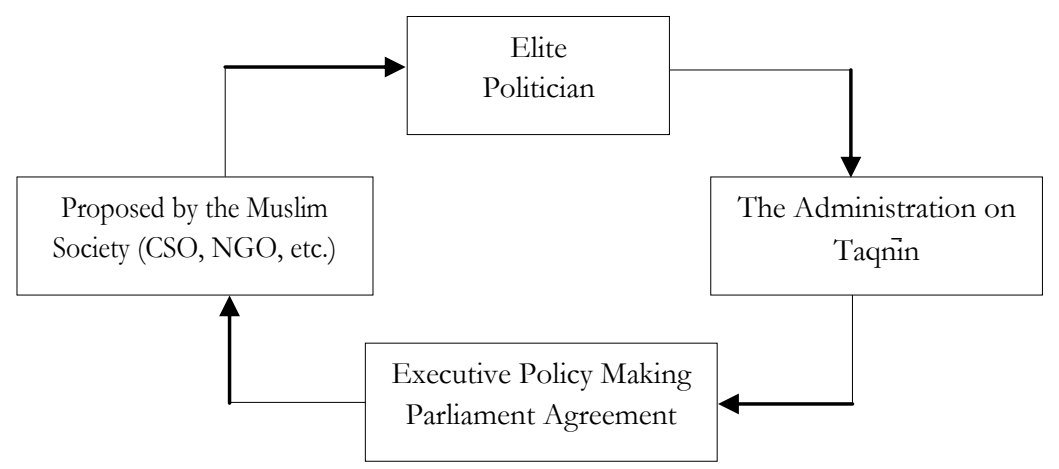

The role of the religious elites and politicians is fundamental to back up the existence of taqnin in Indonesia. Their position in the power circle, especially in the parliament (the legislatives) and the

45 The scheme modified by the researcher by considering the existing data to ease the analysis on how the taqnin is implemented in Indonesia. 
ministries (the executives) makes the bill on Islamic law easier for approval by the policy makers.

\section{Mapping the Taqnin in Indonesia: Opportunity and Challenges}

Since Indonesia independence up to now, the dynamic and transformation of Islamic law has been a political issue in this country. It is true that in the era of the Sukarno's Old Order, the elites busily involved in the resistance against the returning Dutch and internal conflicts of the new state that made impossible to propose the taqnin of Islamic law. The idea of taqnin was initially begun in 1970s in the initial periods of the New Order Regime. By the time, the development of the Islamic law as a concept can be considered as taqnin. ${ }^{46} \mathrm{It}$ is then these concepts quantitatively become a set of rules and laws become the formal law in this country.

Based on the characteristic of the established law by the government, Islamic law in the country can be classified into: first, the legislation which is formally and materially applied Islamic law, and secondly, the legislation products which is supportive to spirit and principle of Islamic law without the label of Islam. The third, the Islamic law which formally and materially has been transformed as the persuasive and authoritative source of the law. ${ }^{47}$ In all those categories, it seems that the taqnin of Islamic law has developed progressively. ${ }^{48}$

${ }^{46}$ Especially it can be seen in the reformation era. Democratization has been opened that make it more possible to implement many more taqnin quantitatively than in the previous era.

47 See, Dadan Muttaqien, Legislasi Hukum Islam; Ilhami Bisri, Sistem Hukum Indonesia: Prinsip-prinsip dan Implementasi Hukum di Indonesia (Jakarta: PT Rajagrafindo Persada, 2005), p. 54.

48 The Act no. 1 of 1974 on Marriage, The Act No. 7 of 1989 on Court on Religious Affairs, The Act No. 7 of 1992 on banking system which allow to apply the principle of profit sharing and it was then substituted by the Act No. 10 of 1998, the Act No. 17 of 1999 on the Pilgrimage, the Act No. 38 of 1999 on the management of zakat which becomes the Act No. 23 of 2011, the Act No. 44 of 1999 on the implementation of special autonomy for Aceh, the Act No. 41 of 2004 on Benefaction, the Act No. 3 of 2006 on The court of Religious Affairs, the Act No. 19 of 2008 on the state sharia obligation, and the Act No. 21 of 2008 on Sharia Banking. Meanwhile, some of the state regulation passed are in the form of the government regulation and the president instruction such as: PP No. 9 of 1975 on the technical guideline for the implementation of the Act of Marriage, PP No. 28 of 1977 of the benefaction of the personal land, PP No. 72 of 1992 of the operationalization of Bank based on the principle of profit sharing, Inpres No. 1 of 1991 on Islamic law compilation. 
However, it is important to underline some critical notes about the weaknesses of the taqnin of Islamic law in Indonesia. Some of them are: First, as it happen in many Muslim populated country, the main coverage of Islamic law is on private matters, especially family matters such as marriage, waqf and inheritance, and Islamic banking and finance. It has not covered the jinayah (Islamic penal law). Most of Indonesian criminal law is still derived from the colonial law. Secondly, since Islamic legislation is a product of political negotiation, those regulation and law do not necessarily follow every word of its original features. For example, the law on marriage and management of zakat does not contain any punishment when the law is ignored or breached.

The third, there is a tendency among certain Muslims to ignore Islam-based positive laws when the laws contradict their interpretation of Islamic law. For instance, many Muslims still consider that marriage registration, which is sanctioned by the law, unnecessary because Islamic law does not obliges that. Likewise, they do not heed the judicial divorce procedure, since it is not identical with the conventional interpretation of Islamic law.

The following is the table of taqnin cited from al-ahkam alshar'iyyah:

Tabel 1. The domain of Taqnin in Indonesia

\begin{tabular}{|c|c|c|}
\hline $\begin{array}{c}\text { Has been made as } \\
\text { Taqnin }\end{array}$ & $\begin{array}{l}\text { Has not been } \\
\text { made as Taqnin }\end{array}$ & Note \\
\hline $\begin{array}{l}\text { 1. Marriage } \\
\text { 2. Divorce } \\
\text { 3. Will and Bequest } \\
\text { 4. Waqf (endowment) } \\
\text { 5. Haj } \\
\text { 6. Zakat } \\
\text { 7. Family Court on } \\
\text { Religious affair } \\
\text { 8. Islamic banking and } \\
\text { Finance }\end{array}$ & & $\begin{array}{l}\text { Assigned in the era of } \\
\text { New Order and } \\
\text { reformation era }\end{array}$ \\
\hline & $\begin{array}{l}\text { 1. Jinayah } \\
\text { (Criminal case) } \\
\text { 2. Politics }\end{array}$ & $\begin{array}{l}\text { Has not been assigned in } \\
\text { national law, but there is } \\
\text { bylaws as part of special } \\
\text { autonomy in Aceh }\end{array}$ \\
\hline
\end{tabular}


It can be seen that the taqnin is still the domain of family matters and private issues. The fact that there are several Islamic parties does not necessarily they unite to fight for greater application of Islamic law. Instead, all agree that Indonesia should not become an Islamic state, since it would lead into the potential break up of Indonesia. National Awakening Party (Partai Kebangkitan Bangsa), Prosperous Justice Party (Partai Keadilan Sejahtera), National Mandate Party (Partai Amanat Nasional) and United Development Party (Partai Persatuan Pembangunan) believe that greater enactment of Islamic law will turn Indonesia a step closer to become an Islamic state. Besides, the identity of those parties always combines religiosity (Islam) and nationalism (commitment to unitary state of Indonesia). Moreover, the total vote of combined Islamic parties is around $20 \%$, whereas the rest $80 \%$ are nationalist parties with no interest whatsoever in Islamic legislation. Admittedly, this is the irony of a country with more than $80 \%$ Muslim population.

Therefore, there is a need to have a grand strategy to achieve greater Islamic legislation Indonesia. The foremost is the strategy to unite the voice of Muslims on this issue. Many devout Muslims now hold key positions in the state. This situation should be capitalized. However, considering the typology of Indonesian Muslims at the moment, a unified front to taqnin is unforeseeable and destined to fail.

However, there might be uncoordinated moves toward Islamic legislation by individual figures who now get portfolio in the ministries and are members of parliament. They do have power to reinforce its process. This, though, should not be a campaign with the banner of Islam. Instead, they should promote Islamic legislation in substance. In doing so, it is easier to convince the nationalists such as President Joko Widodo and his Party. As it happened in the past with all presidents, the effort of Islamic legislation is always a political process which involve negotiation and diplomacy. Muslims might get what they want in term of Islamic positive law but in turn they must pay allegiance to the contemporary political arrangement of secular Indonesia. Muslims should be aware of this and ready to make temporary sacrifices. In brief, it is still plausible to propose the Islamic law as part of the positive law both quantitatively and qualitatively. It is also reasonable to do that since it is not easy to make regulation and law based on Islamic values. It is a long and winding political process. 


\section{Conclusion}

The development of taqnin in Indonesia should be appreciated in accordance with many government regulations substantially and materially reflect the Islamic law. It has involved various parties contributions. Since the existing taqni ${ }^{-}$ns are still limited in many ways. Therefore, a strategy is needed to achieve taqni ${ }^{-} \mathrm{n}$ (Islamic legislation) in Indonesia. Generally, there are three forms of qānun. The first is the Islamic law lock, stock and barrel. Second, the Islamic law which is in its process of taqnin is represented as the material source of the law. The third, the Islamic law which its spirit and values has been transformed into authoritative sources of the law. Indonesia is not an Islamic state even though it is inhabited mostly by Muslims. Therefore, they should be a formula to give religious relief for those Muslim citizens.

Pejorative assumption stating that Indonesia will be an Islamic state by the existence of those taqnin is groundless. Since taqnin is merely an effort to accommodate the Muslims' interest on their sharia in their own life. This automatically will strengthen the nation state. Therefore, without transforming to be an Islamic state, the taqnin of Islamic law should be continuously encouraged and developed. The national consensus as the state based on Pancasila has guaranteed the growth of pluralism. It means that Indonesian Muslims can live with their qānūn and Islamic values.! 


\section{References}

\section{Books and Articles}

Abdullah, Taufiq. Sejarah dan Masyarakat. Jakarta: Pustaka Firdaus, 1987.

Ali, Muhammad Daud. Hukum Islam. Jakarta: Raja Grafindo Persada, 1993.

Al-Jauziyah, Ibnu al-Qayyim. I'lam al-Muwaqi'īn, Juz III.

Al-Zarqa, Mushtafa. al-Madkhal al-Fiqh al-'Am, Juz I. Beirut: Dār alQalam, $1418 \mathrm{H}$.

Anis, Ibrahim. al-Mu'jam al-Wašith, Juz 2.

Anshari, Endang Saifudin. Piagam Jakarta 22 Juni 1945. Bandung: Pustaka Perpustakaan Salman ITB, 1981.

Anwar, M. Syafi'i. Pemikiran dan Aksi Islam Indonesia: Sebuah Kajian Politik tentang Cendekiawan Muslim Orde Baru. Jakarta: Paramadina, 1995.

-------. Politik Akomodasi Negara dan Cendekiawan Muslim Orde Baru: Sebuah Retrospeksi dan Refleksi. Bandung: Mizan, 1995.

Arifin, Bustanul. Eksistesi, Konsolidasi dan Aktualisasi Pengadilan Agama. Paper presented in IAIN Syarif Hidayatullah, Jakarta, 22 Desember 1993.

---------. Pelembagaan Hukum Islam di Indonesia. Jakarta: Gema Insani Press, 1996.

Bek, Muhammad al-Khudari. Tärikh Tashrì al-Islämi. Beirut: Dār alFikr, 1988.

Bisri, Ilhami. Sistem Hukum Indonesia; Prinsip-prinsip dan Implementasi Hukum di Indonesia. Jakarta: PT Rajagrafindo Persada, 2005.

Coulson, Noel J. The History of Islamic Law. Edinburgh: n.p., 1964. 
Fanani, Muhyar. Membumikan Hukum Langit: Nasionalisasi Hukum Islam Dan Islamisasi Hukum Nasional Pasca Reformasi. Yogyakarta: Tiara Wacana, 2008.

Hallaq, Wael B. The Origins and Evolution of Islamic Law. Cambridge: Cambridge University Press, 2005.

Harisudin, M.N. Imu Ushul al-Fiqh I. Jember: IAIN Press, 2014.

J ND. Anderson. Hukum Islam di Dunia Modern, transl. Mahnun Husein. Yogyakarta: PT. Tiara Wacana, 1994.

Ka'bah, Rifal. Hukum Islam di Indonesia. Jakarta: Universitas Yarsi, 1999.

Kan, J. Van and J.H. Beekhuis. Pengantar Ilmu Hukum. Jakarta: Pustaka Sarjana, n.d.

Lev, S. Hukum dan Politik di Indonesia. Jakarta: LP3ES, 1990.

Mahmasani, Sobhi. Filsafat Hukum Islam. Bandung: al-Maarif, 1976.

Mahmood, Tahir. Personal Law in Islamic Countries. New Delhi: Times Press, 1987.

Mardjono, Hartono. Menegakkan Shariat Islam dalam Konteks Keindonesiaan. Bandung: Mizan, 1977.

Mudzhar, M. Atho. "Pengaruh Faktor Sosial Budaya terhadap Produk Pemikiran Hukum Islam." Jurnal Mimbar Hukum, 4, II. Jakarta: Al-Hikmah dan Ditbinbaperta Islam, 1991.

Munawir, Ahmad Warson. Kamus Munawwir. Yogyakarta: Yayasan Ali Maksum Ponpes Krapyak Yogayakarta, 1984.

Muttaqien, Dadan. Legislasi Hukum Islam di Indonesia dalam Perspektif Politik Hukum. Paper presented in Postgraduate program, Indonesian Islamic University (UII) Yogyakarta, 6 March 2009.

Ramulyo, Idris. Azas-azas Hukum Islam. Jakarta: Sinar Grafika, 1997.

Rofiq, Ahmad. Pembaruan Hukum Islam di Indonesia. Yogyakarta: Gama Widya, 2001.

Schacth, Josep. Pengantar Hukum Islam. Bandung: Nuansa, 2010.

Sirajuddin. Legislasi Hukum Islam di Indonesia. Yogyakarta: Pustaka Pelajar, 2008. 
Suminto, Aqib. Politik Islam di Hinda Belanda. Unpublished dissertation, IAIN Syarif Hidayatullah Jakarta, 1985.

Wahyuni, Sri. "Politik Hukum Islam di Indonesia; Studi Terhadap Legislasi Kompilashi Hukum Islam." Jurnal Mimbar Hukum, 59, XIV (2003).

www.nu.or.id

Yaswirman. Hukum Keluarga. Jakarta: PT Radja Grafindo Persada, 2013. 